\title{
Emissions of methane and carbon dioxide during anaerobic decomposition of aquatic macrophytes from a tropical lagoon (Sáo Paulo, Brazil)
}

Emissôes de metano e dióxido de carbono da decomposição de macrófitas aquáticas de uma lagoa tropical (São Paulo, Brasil)

Irineu Bianchini Jr. ${ }^{1,2}$, Marcela Bianchessi da Cunha-Santino ${ }^{1}$, Francisco Romeiro ${ }^{2}$ and Alexandre Luccas Bitar ${ }^{2}$

${ }^{1}$ Laboratório de Bioensaios e Modelagem Matemática, Departamento de Hidrobiologia, Universidade Federal de São Carlos - UFSCar, Rod. Washington Luis, Km 235, CP 676, CEP 13565-905, São Carlos, SP, Brazil e-mail: irineu@power.ufscar.br, cunha_santino@ufscar.br

\author{
${ }^{2}$ Programa de Pós Graduação em Ecologia e Recursos Naturais - PPG-ERN, \\ Universidade Federal de São Carlos - UFSCar, Rod. Washington Luis, Km 235, \\ CP 676, CEP 13565-905, São Carlos, SP, Brazil \\ e-mail: romeiro@rocketmail.com
}

\begin{abstract}
Aim: Massive accumulations of aquatic sedimentary plant are the main source of $\mathrm{CH}_{4}$ and $\mathrm{CO}_{2}$ emissions in floodplain lakes. To examine this connection, this study measured $\mathrm{CO}_{2}$ and $\mathrm{CH}_{4}$ formation during anaerobic decomposition of aquatic macrophytes from a floodplain lake; Methods: Methane formation was determined to the intrinsic characteristics of the debris, and the experimental (physical and chemical) conditions. Production of $\mathrm{CH}_{4}$ and $\mathrm{CO}_{2}$ were measured during anaerobic degradation of seven aquatic macrophytes: Cabomba furcata, Cyperus giganteus, Egeria najas, Eichhornia azurea, Ludwigia inclinata, Oxycaryum cubense, and Utricularia breviscapa, all of which inhabit the littoral zone of the lagoon studied; Results: Overall, methanogenesis was more sensitive to temperature variation than gross anaerobic mineralization. Although the metabolic routes that generate $\mathrm{CO}_{2}$ were always predominant, as a competing process methanogenesis was favored by increasing temperature to the detriment of $\mathrm{CO}_{2}$ formation. Although several factors (such as $\mathrm{pH}$, redox potential, salinity and nutrients availability) influenced yields of the final degradation products, temperature and detritus chemical composition were, in a first approach, the key factors in $\mathrm{CH}_{4}$ formation. In the oxbow lakes of the Mogi-Guaçu River Floodplain, especially Óleo Lagoon, on average, 10\% of the total carbon can be regarded as the yield of $\mathrm{CH}_{4}$ formation derived from aquatic macrophyte decay, while the remaining carbon $(90 \%)$ became $\mathrm{CO}_{2}$.
\end{abstract}

Keywords: methane, anaerobic decomposition, aquatic macrophytes, wetland, floodplain lakes, Mogi-Guaçu River, Óleo Lagoon.

Resumo: Objetivo: Acúmulos intensos de plantas nos sedimentos são importantes fontes de emissões de $\mathrm{CH}_{4}$ e $\mathrm{CO}_{2}$ em lagoas de várzea de inundação. Nesse estudo foram determinadas as formaçôes de $\mathrm{CH}_{4}$ e $\mathrm{CO}_{2}$ da decomposição anaeróbia de macrófitas aquáticas de uma lagoa marginal; Métodos: A formação do metano foi determinada com base nas características intrínsecas dos detritos e das condiçôes experimentais. As produçóes de $\mathrm{CH}_{4}$ e $\mathrm{CO}_{2}$ foram determinadas durante a degradaçăo de sete espécies de macrófitas aquáticas: Cabomba furcata, Cyperus giganteus, Egeria najas, Eichhornia azurea, Ludwigia inclinata, Oxycaryum cubense, and Utricularia breviscapa, todas provenientes da zona litorânea da lagoa marginal selecionada; Resultados: De modo geral, a mentanogênese foi mais sensível à variação da temperatura que os demais processos de mineralização. Embora as rotas metabólicas que geraram o $\mathrm{CO}_{2}$ sempre predominaram, a formaçâo do metano foi favorecida com o incremento da temperatura em detrimento da geraçáo de $\mathrm{CO}_{2}$. Enquanto vários fatores (e.g. $\mathrm{pH}$, potencial redox, salinidade, disponibilidade de nutrientes) influenciaram os rendimentos dos produtos finais da degradação, a temperatura e a composição química dos detritos foram, de modo geral, os fatores mais importantes para a formação do $\mathrm{CH}_{4}$. Nas lagoas marginais da várzea de inundação do rio Mogi-Guaçu e em especial na lagoa do Óleo, em média, $10 \%$ do carbono dos detritos de macrófitas devem ser convertidos em $\mathrm{CH}_{4}$ enquanto os demais (90\%) em $\mathrm{CO}_{2}$.

Palavras-chave: metano, decomposição aneróbia, macrófitas aquáticas, pântano, lagos de várzea, rio Mogi-Guaçu, lagoa do Óleo. 


\section{Introduction}

Floodplain wetlands are among the most productive natural environments and are often characterized as having large inputs of detritus (Merritt andLawson, 1992; Neiff et al., 2006). These systems are driven by hydrologic pulses, produced by oscillations in river water level and lateral overflow that determine floodplain conditions (Powell et al., 2008). Thus, floods are a key factor controlling the biota and biogeochemical cycles in floodplain systems (Junk et al., 1989; Neiff, 1990a, b). Some flooding areas contain mainly shallow lakes, environments favorable for the growth of aquatic macrophyte communities (Scheffer, 2004). Furthermore, aquatic macrophytes support the food webs, provide shelter for small animals, change the nutrient dynamics of the system, and hamper sediment resuspension (Dorn et al., 2001; Thomaz et al., 2006).

Typically, the aquatic macrophytes tissues and phytoplankton cells are the major sources of autochthonous detritus within wetlands. The cytoplasm and the exudates of these plants comprise the main source of labile organic carbon (Peret and Bianchini Jr., 2004; Hanamachi et al., 2008). The supporting tissues of macrophytes are a significant source of refractory carbon (i.e. particulate organic matter). Aquatic plant detritus accumulates heavily over sediments and may be the main source of $\mathrm{CH}_{4}$ and $\mathrm{CO}_{2}$ emissions in floodplain lakes. Tropical systems may account for $60 \%$ of global atmospheric $\mathrm{CH}_{4}$ emissions (Wang et al., 1996). Pantanal floodplain in Brazil, a tropical wetland, is estimated to contribute with $3.3 \%$ of global $\mathrm{CH}_{4}$ emission (Marani and Alvalá, 2007). Methane production is regulated mainly by $\mathrm{O}_{2}$ concentration, $\mathrm{pH}$, temperature, salinity, organic substrates, and nutrient availability. The amount of $\mathrm{CH}_{4}$ emitted from wetlands is further influenced by a large number of factors, including plant physiology, community composition, and hydrology. In addition to their direct effects on methanogen physiology, these factors influence the process indirectly by regulating the flow of methanogenic substrates from fermenting and syntrophic microorganisms. Methanogenesis can be limited by any single link in the chain of reactions that begins with detrital inputs (Megonigal et al., 2004).

Considering the high production of detritus from aquatic macrophyte in tropical wetlands (Bianchini Jr. and Rocha, 2006; Batzer et al., 2007) and the importance of environmental variables over $\mathrm{CH}_{4}$ production, we conducted a study to understand the mechanisms that control $\mathrm{CH}_{4}$ formation; by evaluating $\mathrm{CO}_{2}$ and $\mathrm{CH}_{4}$ production, during anaerobic decomposition of seven species of aquatic macrophytes from an oxbow lake located in a tropical floodplain area. We hypothesized that $\mathrm{CH}_{4}$ formation is controlled by the chemical composition of organic resource, i.e. species of macrophyte and its structures (e.g. roots, rhizomes and leaves and labile and refractory compounds) and the physical (i.e. temperature) and chemical (i.e. interactions between particulate and dissolved organic matter) characteristics of the environment (i.e. extrinsic factors).

\section{Material and Methods}

\subsection{Site description}

Water and aquatic macrophyte samples were collected from the Óleo Lagoon ( $21^{\circ} 36^{\prime} \mathrm{S}$ and $47^{\circ} 49^{\prime} \mathrm{W}$ ), which is located in the municipality of Luiz Antônio (São Paulo State, Brazil). The lagoon, part of a group of floodplain lakes, is located inside the Jataí Ecological Station. The regional climate has two well-defined seasons (Ballester and Santos, 2001): rainy (November-April) and dry (May-October), with average temperatures of $26.8 \pm 1.7^{\circ} \mathrm{C}$ and $22.4 \pm 1.3^{\circ} \mathrm{C}$, respectively (Cunha-Santino, 2003); the regional climate is AW according to Köppen climate classification (i.e. rainy summer and dry winter).

The lagoon system, a part of the Mogi-Guaçu river floodplain, is formed by shallow oxbow lakes with heavy aquatic macrophyte density (Nogueira and Esteves, 1990); flooding connects some of these lakes to the river (Santos and Mozeto, 1992). Anoxic conditions usually occur in the rainy season (Ballester and Santos, 2001). Anoxic conditions are established at $2.5 \mathrm{~cm}$ depth in the Óleo Lagoon sediments (Cunha-Santino, 2003). Temperatures at the sediment level of the lagoon (ca. $5 \mathrm{~m}$ ) range between 15.8 and $25.6{ }^{\circ} \mathrm{C}$ with an average of $21.7 \pm 2.8{ }^{\circ} \mathrm{C}$ (Petracco, 2006). The littoral zone is highly colonized by aquatic macrophytes. The following species were registered Cabomba furcata, Ceratophyllum submersum, Egeria najas, Eichhornia azurea, Ricciocarpus natans, Cyperus giganteus, Ludwigia inclinata, Najas conferta, Salvinia auriculata, Oxycaryum cubense, Utricularia breviscapa and Utricularia foliosa (Cunha-Santino, 2003; Petracco, 2006).

\subsection{Experiments}

The aquatic macrophytes (Cabomba furcata, Cyperus giganteus, Egeria najas, Eichhornia azurea, 
Ludwigia inclinata, Oxycaryum cubense, and Utricularia breviscapa) were harvested from various points of the littoral zone of Óleo Lagoon. The plants were washed within lagoon water to remove periphyton, sediment particles, and coarse material (Ogburn et al., 1987). In the laboratory, the plants were washed with tap water, oven-dried $\left(40{ }^{\circ} \mathrm{C}\right)$, and ground. Prior to the assays with $C$. furcata and $C$. giganteus, leachate was extracted by adding $10 \mathrm{~g}$ DW (dry weight) of ground plant (previously sterilized by autoclaving for 15 minutes, at 1 atm and $121{ }^{\circ} \mathrm{C}$; Ward and Johnson, 1996) to a flask containing $1 \mathrm{~L}$ of sterilized deionized water. After 24 hours of cold aqueous extraction $\left(4^{\circ} \mathrm{C}\right)$ (Mфller et al., 1999), the leachate was fractionated from particulate organic matter (POM) by centrifugation (1048 g, 1 hour) and filtered through $0.45 \mu \mathrm{m}$ pore size cellulose ester (Millipore). The remaining POM (i.e. fibers) was considered refractory tissue. Concentrations of dissolved inorganic carbon (DIC) and dissolved organic carbon (DOC) in the leachate were determined by combustion (TOC Analyzer Shimadzu, Model 5000A). Prior to the assays with $O$. cubense, the plants were also fractionated into roots, rhizomes, and leaves. Cell wall fractions (CWF $\approx$ lignin, cellulose and hemicellulose; $\mathrm{n}=3$ for each species) of the plant tissues were determined using neutral detergent and the reflux method (Van Soest and Wine, 1967). Thus, POM was constituted of the fibrous material remainder from the aqueous extraction and or from the leaching during decomposition, and CWF basically refers to the cell wall components, extracted by chemical method.

Water samples for the experiments were collected with a Van Dorn underwater sampler at three lagoon depths (surface, 1.5, and $3.0 \mathrm{~m}$ ). To obtain an integrated sample of lake water, equivalent volumes from different depths were then mixed for sampling in the laboratory. These were filtered through a cellulose ester membrane (Millipore; pore size: $0.45 \mu \mathrm{m}$ ). The DIC and DOC concentrations were determined by combustion (TOC analyzer). To quantify $\mathrm{CH}_{4}$ and $\mathrm{CO}_{2}$ emissions, for each condition, selected incubations were prepared in $1.12 \mathrm{~L}$ glass flasks. Three contained plant fragments $(7.0 \mathrm{~g} \mathrm{DW})$ and lagoon water $(1.0 \mathrm{~L})$ as source of indigenous microorganisms; the other two had only lagoon water (control). After prepared, the incubations were bubbled with nitrogen (to reach anaerobic condition) and the flasks were kept in the dark under controlled temperature (ca. $20^{\circ} \mathrm{C}$ ). In the incubations (with fragments of $E$. najas,
E. azurea, L. inclinata, and U. breviscapa) subjected to temperature variation (from 15 to $30{ }^{\circ} \mathrm{C}$ ), $\mathrm{CH}_{4}$ and mineralized carbon (MC) yields were used to calculate the $\mathrm{Q}_{10}$ temperature coefficient (the rate of change of a biological or chemical reaction as a result of increasing the temperature by $10^{\circ} \mathrm{C}$ ), according to Winkler et al. (1996). The temperature range chosen for the experiments comprised the seasonal variation registered to the Óleo Lagoon (Petracco, 2006). Periodically, during a span of 140 to $200 \mathrm{~d}, \mathrm{CO}_{2}$ and $\mathrm{CH}_{4}$ production was estimated by sampling the gases enclosed in the incubation headspaces $(120 \mathrm{~mL})$. Samples were taken with a syringe $(1.0 \mathrm{~mL})$ by piercing the silicone septa that sealed the flask. The gas samples were analyzed using gas chromatography (CG Construmaq, Model 370; with thermal conductivity detector and Porapak N column; carrier gas: hidrogen). Peak areas were quantified from $\mathrm{CO}_{2}$ and $\mathrm{CH}_{4}$ standard curves. After being measured, gases were expurgated from incubations by nitrogen bubbling (during 5 minutes) to keep the determinations on a daily rates basis. Measuring procedures continued until $\mathrm{CH}_{4}$ daily rates became null.

At the end of the experiments the residues were fractionated by filtration through nylon mesh $(0.4 \mathrm{~mm})$. The filtrate was then centrifuged $(1048 \mathrm{~g}$, 1 hour) and the supernatant were filtered through cellulose-ester membranes $(0.22 \mu \mathrm{m}$ Millipore, previously washed with $250 \mathrm{~mL}$ distilled water). The particulate material was dried (at $50{ }^{\circ} \mathrm{C}$ for 48 hour) and then weighed. The carbon contents of particulate detritus were quantified by a $\mathrm{CHN}$ analyzer (Carlo Erba model EA 1110). The DOC and DIC concentrations were measured with a TOC analyzer, as describes previous. From the $\mathrm{CO}_{2}$ and $\mathrm{CH}_{4}$ measures and initial and final carbon contents (DOC, DIC, POC) the entire carbon budget and the yields of $\mathrm{CO}_{2}$ and $\mathrm{CH}_{4}$ were calculated. The temperature variation and C-budgets were used to compare the methanogenesis from the organic resources (i.e. entire macrophytes, leachate, roots, leaves and rhizomes of the Scirpus cubenses and POM and leachate of the Cabomba furcata and Cyperus giganteus) decompositions. Linear correlations were also used to compare the results $\left(\mathrm{CO}_{2}\right.$ and $\mathrm{CH}_{4}$ yields) with chemical composition of resources.

\section{Results}

The cell wall fraction (CWF) varied from $27.5 \%$ (C. furcata) to $80.7 \%$ (O. cubense), which on average represented $55.6 \%$ of the cell wall tissues of the selected aquatic plants (Table 1). 
Macrophyte fragments showed the predominance of particulate organic matter over the soluble fractions (i.e. leachate: mean $30.8 \%$, SD 5.3\%). On average, POM represented $69.2 \%$ of plant tissues; dissolution potential (i.e. hydrosoluble cytoplasm compounds) corresponded to $30.8 \%$. Leachate varied from 22.0 (C. furcata) to $35.9 \%$ (O. cubense). Inorganic compounds prevailed in the soluble fractions (mean: $21.6 \%$, SD: $8.2 \%$ ); C content from leachate varied from $4.6 \%$ (C. giganteus) to $17.0 \%$ (U. breviscapa; Table 1).

Overall, tree stages were identified for methanogenesis: in the first, $\mathrm{CH}_{4}$ was not produced (lag stage); in the second, $\mathrm{CH}_{4}$ began to be produced, reaching the highest rates; the third stage was characterized by a decrease in the rates, until reaching zero. The changes of daily rates of the $\mathrm{CO}_{2}$ and $\mathrm{CH}_{4}$ formation (from $\mathrm{O}$. cubense decomposition at $20^{\circ} \mathrm{C}$ ) were exemplified in the Figure 1 . On a carbon basis, decay of E. najas at $27{ }^{\circ} \mathrm{C}$ produced highest methane amounts (31.3\%) followed by its decomposition at $22.4{ }^{\circ} \mathrm{C}$ and the decay of O. cubense $(27.1 \%)$ at $20^{\circ} \mathrm{C}$. The pathway for $\mathrm{CO}_{2}$ formation in all experiments predominated over methanogenesis; in some cases, methane production was not recorded (decompositions of POM and leachate from C. giganteus, and incubations maintained under low temperatures). On average, considering similar temperatures (ca. $20^{\circ} \mathrm{C}$ ), $10.1 \%$ of the carbon was converted into $\mathrm{CH}_{4}$ by anaerobic decay of aquatic macrophytes (Table 2).

Considering the 4 assays (incubations with E. najas, E. azurea, L. inclinata, and U. breviscapa) methane generation and anaerobic mineralization yields depended on the temperature. Among the selected macrophytes, methane formation from $U$. breviscapa degradation $\left(\mathrm{Q}_{10}: 6.49\right)$ was more susceptible to temperature changes, a result followed by decay of $L$. inclinata $\left(\mathrm{Q}_{10}: 4.42\right)$, E. najas $\left(\mathrm{Q}_{10}\right.$ :
2.29), and E. azurea $\left(\mathrm{Q}_{10}: 1.12\right)$. On the other hand, $Q_{10}$ values of anaerobic decay of macrophytes were very similar (E. najas: 1.36 ; E. azurea: 1.22 ; L. inclinata: 1.13 ; U. breviscapa: 1.54$)$. Considering $\mathrm{Q}_{10}$ values, methane formation (mean: 3.58) was ca. 3-fold more affected by temperature than was anaerobic mineralization (mean: 1.31). The $\mathrm{CH}_{4}-\mathrm{Q}_{10}$ values were inversely proportional to CWF $\left(r^{2}=0.99\right)$. In all experiments, the time required to initiate methane formation decreased with temperature. The yields of $\mathrm{CH}_{4}$ formation at the same temperature $\left(\mathrm{ca} .20^{\circ} \mathrm{C}\right)$ comprise the
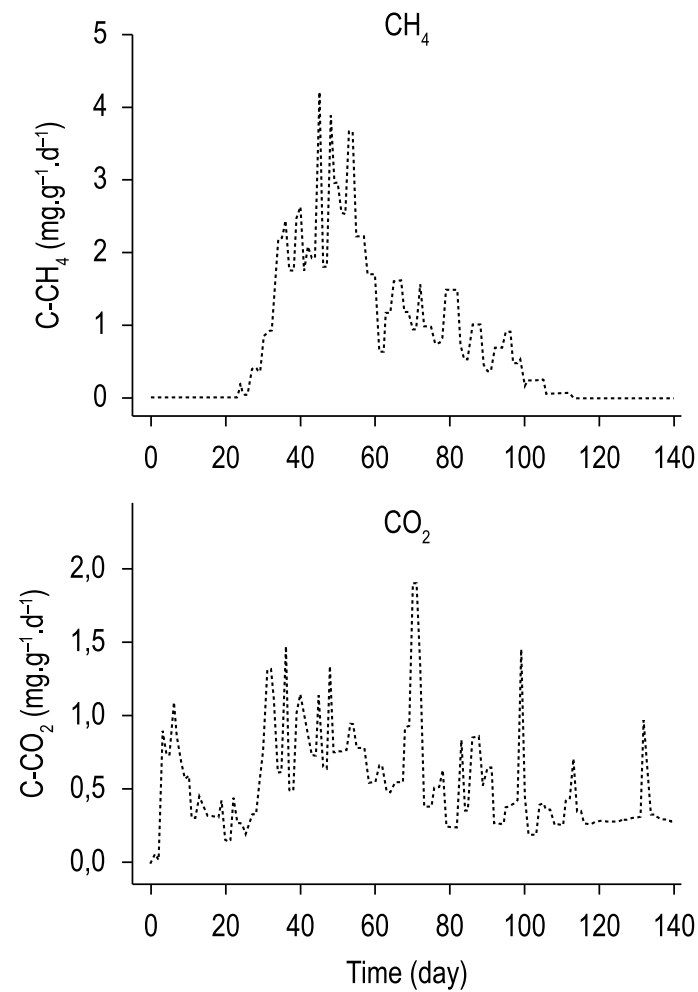

Figure 1. Variations of $\mathrm{CH}_{4}$ and $\mathrm{CO}_{2}$ daily rates from anaerobic decomposition of Oxycaryum cubense (at $\left.20^{\circ} \mathrm{C}\right)$.

Table 1. Chemical composition of aquatic macrophytes tissues. Where: $\mathrm{CWF}=$ cell wall fraction; $\mathrm{POM}=$ particulate organic matter; Leachate $=$ leachate potential; C-leachate $=$ organic carbon content of leachate; IN-Leachate $=$ inorganic content of leachate.

\begin{tabular}{lccccc}
\hline \multicolumn{1}{c}{ Aquatic macrophyte } & CWF $(\%)$ & POM (\%) & Leachate (\%) & C-Leachate (\%) & IN-Leachate (\%) \\
\hline Cabomba furcata & 27.5 & 78.0 & 22.0 & 14.3 & 7.7 \\
Cyperus giganteus & 73.7 & 72.8 & 27.2 & 4.6 & 22.6 \\
Egeria najas & 61.0 & 72.7 & 27.3 & 8.7 & 18.6 \\
Eichhorina azurea & 66.7 & 64.6 & 35.4 & 8.2 & 27.2 \\
Ludwigia inclinata & 48.3 & 65.1 & 34.9 & 6.6 & 28.3 \\
Utricularia breviscapa & 31.5 & 67.4 & 32.6 & 17.0 & 15.7 \\
Oxycaryum cubense & 80.7 & 64.1 & 35.9 & 5.0 & 30.9 \\
Mean & 55.6 & 69.2 & 30.8 & 9.2 & 21.6 \\
SD & 20.5 & 5.3 & 5.3 & 4.7 & 8.2 \\
\hline
\end{tabular}


Table 2. Parameters related with methane formation during decay of different resources linked with aquatic macrophytes. Where: T: temperature of incubation; $\mathrm{C}_{-} \mathrm{CH}_{4}$ : the yield of methane (on carbon basis); DIC: dissolved inorganic carbon; $\mathrm{C}_{-} \mathrm{CO}_{2}$ : the yield of dioxide of carbon (on carbon basis); $\mathrm{MC}$ : mineralization yield (on carbon basis); $\mathrm{CH}_{4}-\mathrm{B}$ and $\mathrm{CH}_{4}-\mathrm{E}$ : days of beginning and end of methane formation, respectively; Time = accumulate days of incubations.

\begin{tabular}{|c|c|c|c|c|c|c|c|c|}
\hline Resource & $\mathrm{T}\left({ }^{\circ} \mathrm{C}\right)$ & $\mathrm{C}-\mathrm{CH}_{4}(\%)$ & $\mathrm{C}-\mathrm{CO}_{2}(\%)$ & DIC (\%) & MC (\%) & $\mathrm{CH}_{4}-\mathrm{B}$ (day) & $\mathrm{CH}_{4}-\mathrm{E}$ (day) & Time (day) \\
\hline Cabomba furcata & 20 & 11.5 & 17.4 & 3.2 & 32.1 & 21 & 140 & 140 \\
\hline POM & 20 & 13.0 & 13.5 & 2.1 & 28.6 & 21 & 140 & 140 \\
\hline Leachate & 20 & 6.3 & 25.8 & 10.5 & 42.6 & 22 & 57 & 140 \\
\hline Cyperus giganteus & 20 & 3.6 & 16.5 & 0.4 & 20.5 & 37 & 125 & 125 \\
\hline POM & 20 & 0.0 & 9.2 & 0.5 & 9.7 & - & - & 125 \\
\hline Leachate & 20 & 0.0 & 75.0 & 0.9 & 75.9 & - & - & 125 \\
\hline \multirow[t]{4}{*}{ Egeria najas } & 17.7 & 13.7 & 30.4 & 2.4 & 46.4 & 61 & 107 & 120 \\
\hline & 20.3 & 23.3 & 22.4 & 6.7 & 52.3 & 47 & 116 & 120 \\
\hline & 22.4 & 28.9 & 20.2 & 9.2 & 58.2 & 16 & 87 & 120 \\
\hline & 27 & 31.3 & 22.4 & 8.5 & 62.2 & 16 & 116 & 120 \\
\hline \multirow[t]{4}{*}{ Eichhorina azurea } & 18.2 & 0.0 & 16.7 & 1.8 & 18.5 & - & - & 120 \\
\hline & 21.4 & 2.4 & 15.0 & 1.7 & 19.1 & 41 & 113 & 120 \\
\hline & 24.8 & 2.0 & 16.7 & 2.9 & 21.7 & 24 & 95 & 120 \\
\hline & 26.8 & 2.7 & 14.9 & 3.9 & 21.5 & 17 & 114 & 120 \\
\hline \multirow[t]{4}{*}{ Ludwigia inclinata } & 15 & 0.4 & 21.2 & 1.1 & 22.7 & 99 & 174 & 200 \\
\hline & 20.1 & 2.3 & 21.9 & 0.9 & 25.1 & 39 & 200 & 200 \\
\hline & 25 & 8.9 & 16.8 & 1.1 & 26.8 & 22 & 167 & 200 \\
\hline & 29.9 & 9.8 & 16.5 & 0.8 & 27.1 & 15 & 198 & 200 \\
\hline \multirow[t]{4}{*}{ Utricularia breviscapa } & 15.3 & 0.0 & 29.7 & 1.4 & 31.1 & - & - & 138 \\
\hline & 20.8 & 0.4 & 40.5 & 5.4 & 46.4 & 61 & 120 & 138 \\
\hline & 25.7 & 2.3 & 49.6 & 4.1 & 56.1 & 21 & 98 & 138 \\
\hline & 30.3 & 2.6 & 52.9 & 3.8 & 59.3 & 21 & 82 & 138 \\
\hline Oxycaryum cubense & 20 & 27.1 & 19.0 & 0.9 & 47.0 & 24 & 130 & 140 \\
\hline roots & 20 & 21.7 & 17.0 & 0.9 & 39.6 & 28 & 140 & 140 \\
\hline rhizomes & 20 & 7.1 & 17.6 & 1.1 & 25.8 & 41 & 139 & 140 \\
\hline leaves & 20 & 3.0 & 24.7 & 0.5 & 28.2 & 44 & 130 & 140 \\
\hline Mean (at $20^{\circ} \mathrm{C}$ ) & & 10.1 & 21.8 & 2.7 & 34.7 & & & \\
\hline
\end{tabular}

relation with the chemical characteristics of plant tissues (CWF, POM, leachate, C-leachate, INleachate); Table 2.

After 140 days, $\mathrm{CH}_{4}$ formation and mineralization yields were higher in incubation with non-fractionated detritus of $O$. cubense (27.1 and $19.0 \%$, respectively), followed by that of decayed roots (C- $\mathrm{CH}_{4}: 21.7 \%$ and CM: $\left.17.0 \%\right)$; Table 2.

\section{Discussion}

Macrophyte primary production affects the dynamics and metabolism of several aquatic ecosystems, especially the shallower ones (Wetzel, 2001). Detritus generated in such areas usually support the detritus food chains of littoral zones and might be exported to benthic and pelagic regions. Depending on the environment, most debris produced in littoral regions is composed of aquatic macrophyte detritus, which contributes to sediment diagenesis and biogenic gas emissions. The present study showed methane quantity varying with the type of detritus (i.e. macrophyte species) and its structure (i.e. fibers, leachate, roots, rhizomes, and leaves). In spite of the similarity among the percentages of macrophyte derived POM, macrophyte leachate, C-leachate, and IN-leachate, methane formation varied widely in incubation (at ca. $20{ }^{\circ} \mathrm{C}$ ) yields for E. azurea $(2.4 \%)$ and $O$. cubense $(27.1 \%)$. In contrast, O. cubense presented a CWF $57 \%$ higher than the average of other plants $(\mathrm{CWF}=51.4 \%)$, which we attribute to $\mathrm{CH}_{4}$ formation to decomposition of CWF. A nutrient balance study on these species in a lagoon of this floodplain showed that $O$. cubense accumulated 1.4 times more nutrients than E. azurea in the dry period and 6.9-fold in the rainy season (Nogueira et al., 2000). Thus, aquatic macrophytes can be the main nutrient suppliers of 
these shallow aquatic environments. Moreover, the nutritional composition influences decomposition pathways, in this case favoring methane formation. As for anaerobic decomposition of morphological structures (i.e. roots, rhizomes, and leaves) of O. cubense, heterotrophic organisms showed heavy root consumption ( $\mathrm{MC}=47.0 \%)$ whereas rhizomes were the most refractory detritus $(\mathrm{MC}=25.8 \%)$. In addition, debris with higher ash content (a surrogate of nutrients) was found to lead to higher $\mathrm{CH}_{4}$ production (Romeiro and Bianchini Jr., 2006). Besides the nutrient content of the detritus as a supply source in methane formation, anaerobic degradation of $U$. breviscapa showed strong evidence that the $\mathrm{CH}_{4}$ formation were concomitant with cellulase activity (Cunha-Santino, 2003) and, therefore, dependent on anaerobic degradation of cellulose (Leschine, 1995).

Beyond the specific requirements of methanogenic archaea (e.g. temperature, $\mathrm{pH}$, nutrient and labile carbon availability), in agreement with observed in the present study, enable us to assume that in the Óleo Lagoon methane formation during decomposition of aquatic macrophytes depends overwhelmingly on the input of aquatic macrophyte detritus, i.e. the temporal intensity variation, and on the type and chemical composition of the detritus. In this context, in the Óleo Lagoon, asynchronies were observed between the predominance of the detritus input (autumn - winter) and of the higher values of $\mathrm{CH}_{4}$ emission and denitrification (spring - summer) (Ballester, 1994; Gianotti and Santos, 2000). A mass balance study of aquatic macrophyte detritus for another lake of this floodplain also registered asynchronies (ca. 80 days) between senescence and accumulation of particulate debris in the sediments (Bianchini Jr. and Rocha, 2006). In the case of $U$. breviscapa of Óleo Lagoon, biomass decreases during the cold months (mainly in June-July). Therefore, it can be assumed that during this period senescence of this macrophye contributed strongly to the detritus input (Cunha-Santino, 2003). On the other hand, lesser quantities of Utricularia sp. (i.e. input of detritus) has been reported in Infernão Lagoon (also situated in Mogi-Guaçu River Floodplain) in February (Carlos, 1991), which was attributed to several factors: reduction of subaquatic radiation, turbidity increase, high rainfall index, and flooding.

Considering the yields, methane formation appears not to depend on aquatic macrophyte type (i.e. submersed or emergent). Yields of $\mathrm{CH}_{4}$ formation at around $20{ }^{\circ} \mathrm{C}$ during degradation were found for both submersed (C. furcata: $11.5 \%$; E. najas: $23.3 \%$; and U. breviscapa: $0.4 \%$ ) and emergent species (C. giganteus: $3.6 \%$; E. azurea: 2.4\%; L. inclinata: $2.3 \%$; and O. cubense: $27.1 \%$ ). The results suggest that, besides the chemical composition of the detritus (i.e. nutrients content, labile and refractory organic fractions), the incubation temperature also interferes in $\mathrm{CH}_{4}$ formation. A similar experiment showed that $\mathrm{CH}_{4}$ formation was inhibited by a $\mathrm{pH}$ decrease due to intense $\mathrm{CO}_{2}$ formation during the beginning of C. piauhyensis (i.e. Cabomba furcata) degradation. In this same study, since there were few labile materials, $\mathrm{CH}_{4}$ formation was registered only during $O$. cubense degradation (Cunha-Santino et al., 2006).

Exclusive degradation of the leachate hindered $\mathrm{CH}_{4}$ formation; for C. giganteus leachate (which represents $27.2 \%$ of the detritus mass) methanogenesis may have been blocked by insufficient organic carbon availability (4.6\%) in comparison to that of inorganic compounds (22.6\%). In support of this argument, we supposed that $\mathrm{CH}_{4}$ formation during leachate degradation of C. furcata occurred due to higher organic carbon availability (14.3\%) in its elemental composition. Comparing degradation yields of unfractionated macrophyte detritus with leachate and POM, leachate was assumed to be supplied with sufficient inorganic elements to maintain catabolic routes during unfractionated detritus decomposition.

As commonly verified, temperature was a key factor in $\mathrm{CH}_{4}$ formation (Nozhevnikova et al., 1997) and also in anaerobic mineralization of the aquatic macrophytes (Cunha-Santino, 2003; Bitar et al., 2006). Comparing the results, methanogenesis was more sensitive to temperature changes than was gross anaerobic mineralization. The $\mathrm{Q}_{10}$ values for $\mathrm{CH}_{4}$ production are inside the range usually registered; a compilation of temperature-response studies using wetland soils report an average $\mathrm{Q}_{10}$ of 4.1 for $\mathrm{CH}_{4}$ production (Segers, 1998). Although the metabolic routes that culminate in $\mathrm{CO}_{2}$ were always predominant; methanogenesis rather than $\mathrm{CO}_{2}$ formation was favored by increasing temperature. This variable abbreviated the time required for methanogenesis to begin. Another factor that explain the necessary time for $\mathrm{CH}_{4}$ production is the consumption of alternative electrons acceptor (i.e. denitrification, $\mathrm{Fe}(\mathrm{III})$-reduction and sulfate reduction); in this case, such processes would also be abbreviated with the increase of the temperature (Megonigal et al., 2004). 
The inverse correlation between $\mathrm{CWF}$ and $\mathrm{CH}_{4}-\mathrm{Q}_{10}$ suggest that the cell wall content of detritus induced a differentiation of microorganisms or pathways involved in the formation of the methane. This way, the processes related with the degradation of refractory compounds were less sensitive to the temperature change.

In conclusion, several factors (e.g. temperature, detritus chemical composition) influence the process related to final carbon degradation products. In the case of the oxbow lakes of the Mogi-Guaçu floodplain, with reference to the Óleo Lagoon, this approach supposes that the mean value of methane formation ( $10 \%$ of carbon total) can be considered as the mean yield of $\mathrm{CH}_{4}$ formation derived from aquatic macrophyte decay. The remaining carbon (90\%) formed $\mathrm{CO}_{2}$.

\section{Acknowledgements}

The authors thank Coordenadoria de Aperfeiçoamento de Pessoal de Nível Superior (CAPES; Process: 33001014003P2), Conselho Nacional de Desenvolvimento Científico e Tecnológico (CNPq: Processes: 134457/2003-0 and 300959/2004-4) and Fundação de Amparo à Pesquisa do Estado de São Paulo (FAPESP) for financing these assays (Processes: 98/12564-4, 98/15011-6 and 00/09297-6). We thank Dr. Osvaldo N. Oliveira Jr. (IFSC-USP) and two anonymous reviewers, whose comments improved considerably our manuscript.

\section{References}

BALLESTER, MVR. 1994. Dinâmica de gases biogênicos (CH4, CO2 e O2) na planície de inundação do Rio Mogi-Guaçu (Estação Ecológica de Jataí, SP). São Carlos: Universidade Federal de São Carlos. 172 p.

BALLESTER, MVR. and SANTOS, JE. 2001. Biogenic gases $\left(\mathrm{CH}_{4}, \mathrm{CO}_{2}\right.$ and $\left.\mathrm{O}_{2}\right)$ distribution in a riverine wetland system. Oecologia Brasiliensis, vol. 9, p. 21-31.

BATZER, DP., COOPER, R. and WISSINGER, SA. 2007. Wetland animal ecology. In BATZER, DP. And SHARITZ, RR (Eds.). Ecology of freshwater and estuarine wetlands. Berkeley: University of California Press. p. 242-284.

BIANCHINI Jr., I. and ROCHA, MGB. 2006. Simulação da ciclagem de Scirpus cubensis em uma lagoa marginal tropical (Lagoa do Infernão, São Paulo, Brasil). In SANTOS, JE., PIRES, JSR. and MOSCHINI, LE. (Eds.). Estudos Integrados em Ecossistemas - Estação Ecológica de Jataí. São Carlos: EdUFSCar. p. 159-168.
BITAR, AL., BIANCHINI Jr., I. and CUNHASANTINO, MB. 2006. Formação de metano e de dióxido de carbono da decomposiçáo de Egeria najas Planchon. In SANTOS, JE., PIRES, JSR. and MOSCHINI, LE. (Eds.). Estudos Integrados em Ecossistemas - Estação Ecológica de Jataí. São Carlos: EdUFSCar. p. 205-219.

CARLOS, VM. 1991. Aspectos ecológicos da associação vegetal de Scirpus cubensis na lagoa do Infernão - SP. São Carlos: Universidade Federal de São Carlos. $125 \mathrm{p}$.

CUNHA-SANTINO, MB. 2003. Atividade enzimática, cinética e modelagem matemática da decomposição de Utricularia breviscapa da lagoa do Óleo (Estação Ecológica de Jataí, Luiz Antonio, SP). São Carlos: Universidade Federal de São Carlos. 140 p.

CUNHA-SANTINO, MB., BIANCHINI Jr., I., GIANOTTI, EP. and SILVA, EL. 2006. Degradação anaeróbia de macrófitas aquáticas da Lagoa do Infernão: metanogênese. In SANTOS, JE., PIRES, JSR. and MOSCHINI, LE. (Eds.). Estudos Integrados em Ecossistemas - Estação Ecológica de Jataí. São Carlos: EdUFSCar. p. 143-158.

DORN, JN., CRONIN, G. and LODGE, DM. 2001. Feeding preference and performance of an aquatic lepdopteran on macrophytes: plants hosts as food and habitat. Oecologia, vol. 128, no. 3, p. 406-415.

GIANOTTI, EP. and SANTOS, JE. 2000. Estimativas das taxas de desnitrificação e da densidade de bactérias desnitrificantes na lagoa do Infernáo (Estação Ecológica de Jataí, Luiz Antônio, SP) In SANTOS, JE. and PIRES, JSR. (Eds.). Estudos Integrados em Ecossistemas - Estação Ecológica de Jataí. São Carlos: RiMa Editora. p. 667-674.

HANAMACHI, Y., HAMA, T. and YANAI, T. 2008. Decomposition process of organic matter derived from freshwater phytoplankton. Limnology, vol. 9, no. 1, p. 57-69.

JUNK, WJ., BAYLEY, PB. and SPARKS, RE. 1989. The flood pulse concept in river - floodplain systems. Canadian special publication of fisheries and aquatic sciences, vol. 106, p. 110-127.

LESCHINE, SB. 1995. Cellulose degradation in anaerobic environments. Annual Review of Microbiology, vol. 49, p. 399-426.

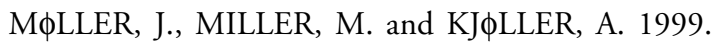
Fungal-bacterial interaction on beech leaves: influence on decomposition and dissolved organic carbon quality. Soil Biology and Biochemistry, vol. 31, no. 3, p. 367-374.

MARANI, L. and ALVALA, PC. 2007. Methane emissions from lakes and floodplains in Pantanal, Brazil. Atmospheric Environment, vol. 41, no. 88, p. 1627-1633.

MEGONIGAL, JP., HINES, ME. and VISSCHER, PT. 2004. Anaerobic metabolism: Linkages to trace gases 
and aerobic processes. In SCHLESINGER, WH. (Ed.). Biogeochemistry. Oxford: Elsevier-Pergamon. p. 317-424.

MERRITT, RW. and LAWSON DL. 1992. The role of leaf litter macroinvertebrates in streams-floodplain dynamics. Hydrobiologia, vol. 248, no. 1, p. 65-77.

NEIFF, AP., NEIFF, JJ. and CASCO, SL. 2006. Leaf litter decomposition in three wetland types of the Paraná River Floodplain. Wetlands, vol. 26, no. 2, p. 558-566.

NEIFF, JJ. 1990a. Ideas para la interpretacion ecológica del Parana. Interciencia, vol. 15, no. 6, p. 424-441.

NEIFF, JJ. 1990b. Aspects of primary productivity in the Lower Paraná and Paraguay Riverine System. Acta Limnogica. Brasiliensia, vol. 3, no. 1, p. 77-113.

NOGUEIRA, FMB. and ESTEVES, FA. 1990. Variação temporal da biomassa de duas espécies de macrofitas aquáticas uma lagoa marginal do rio Mogi-Guaçu (SP). Acta Limnogica. Brasiliensia, vol. 3, no. 2, p. 617-632.

NOGUEIRA, FMB., ESTEVES, FA. and COUTINHO, O. 2000. Importância dos estandes flutuantes de macrófitas aquáticas para as características limnológicas e para a ciclagem de nutrientes da Lagoa do Infernão. In SANTOS, JE. and PIRES, JSR. (Eds.). Estudos Integrados em Ecossistemas - Estação Ecológica de Jatai. São Carlos: RiMa Editora. p. 599-611.

NOZHEVNIKOVA, AN., HOLLIGER, C., AMMANN, CA. and ZEHNDER, AJB. 1997. Methanogenesis in sediments from deep lakes at different temperatures $\left(2-70{ }^{\circ} \mathrm{C}\right)$. Water Science \& Technology, vol. 36, no. 6-7, p. 57-64.

OGBURN III, RW., BREZONICK, PL. and DELFINO, JJ. 1987. Effect of $\mathrm{pH}$ on phosphorous release during macrophyte (Eleocharis sp) decomposition. Water Resources Bulletin, vol. 23, no. 5, p. 829-831.

PERET, AM. and BIANCHINI Jr., I. 2004. Stoichiometry of aerobic mineralization $(\mathrm{O} / \mathrm{C})$ of aquatic macrophytes from a tropical lagoon (São Paulo - Brazil). Hydrobiologia, vol. 528, no. 1-3, p. 167-178.

PETRACCO, P. 2006. Efeito das variáveis abióticas na produção primária de Egeria najas e Utricularia breviscapa da lagoa do Óleo (Estação Ecológica de Jataí, Luiz Antônio, SP). São Carlos: Universidade Federal de São Carlos. 145 p.

POWELL, SJ., LETCHER RA. and CROKE, BFW. 2008. Modelling floodplain inundation for environmental flows: Gwydir wetlands, Australia. Ecological Modelling, vol. 211, no. 3-4, p. 350-362.

ROMEIRO, F. and BIANCHINI Jr., I. 2006. Cinéticas da mineralização anaeróbia de Cyperus giganteus da lagoa do Óleo. In SANTOS, JE., PIRES, JSR. and MOSCHINI, LE. (Eds.). Estudos Integrados em Ecossistemas - Estação Ecológica de Jataí. São Carlos: EdUFSCar. p. 221-237.

SANTOS, JE. and MOZETO, AA. 1992. Programa de análise de ecossistemas e monitoramento ambiental: Estação Ecológica de Jataí (Luiz Antônio, SP). Ecologia de área alagáveis da planície de inundação do rio Mogi-Guaçu. São Carlos: PPGERN/UFSCar. $59 \mathrm{p}$.

SCHEFFER, M. 2004. Ecology of shallow lakes. Dordrecht: Kluwer Academic Publishers. 384p.

SEGERS, R. 1998. Methane production and methane consumption: a review of processes underlying wetland methane fluxes. Biogeochemistry, vol. 41, no. 1, p. 23-51.

THOMAZ, SM., PAGIORO, TA., BINI, LM. and MURPHY, KJ. 2006. Effect of reservoir drawdown on biomass of three species of aquatic macrophytes in a large sub-tropical reservoir (Itaipu, Brazil). Hydrobiologia, vol. 570, no. 1, p. 53-59.

VAN SOEST, PJ. and WINE, RH. 1967. Use of detergents in the analysis of fibrous feeds. IV. Determination of plant cell wall constituents. Journal of $A O A C$, vol. 50 , no. 1, p. 50-55,

WANG, Z., ZENG, D. and PATRICK, WH. 1996. Methane emissions from natural wetlands. Environmental Monitoring and Assessment, vol. 42, no. 1-2, p. 143-161.

WARD, AK. and JOHNSON, MD. 1996. Heterotrophic microorganisms. In HAUER, FR. and LAMBERTI, GA. (Eds.). Methods in stream ecology. San Diego: Academic Press. p. 233-268.

WETZEL, RG. 2001. Limnology - Lake and river ecosystems. San Diego: Academic Press/Elsevier. 1006p.

WINKLER, J., CHERRY R. and SCHLESINGER, W. 1996. The $Q_{10}$ relationship of microbial respiration in a temperate forest soil. Soil Biology and Biochemistry, vol. 28, no. 8, p. 1067-1072.

Received: 16 February 2010 Accepted: 20 August 2010 